Satellite image analysis of human caused changes in the tundra vegetation around the city of Vorkuta, north-European Russia

Virtanen, $\mathrm{T}$.

Elsevier

2002

Virtanen, T. et al. 2002. Satellite image analysis of human caused changes in the tundra vegetation around the city of Vorkuta, north-European Russia. Environmental pollution pÿ120(3): 647658.

http://hdl.handle.net/1975/279

Downloaded from Helda, University of Helsinki institutional repository.

This is an electronic reprint of the original article.

This reprint may differ from the original in pagination and typographic detail.

Please cite the original version. 


\title{
Satellite image analysis of human caused changes in the tundra vegetation around the city of Vorkuta, north-European Russia
}

\author{
Tarmo Virtanen ${ }^{\mathrm{a}, *}$, Kari Mikkola ${ }^{\mathrm{a}}$, Elena Patova ${ }^{\mathrm{b}}$, Ari Nikula ${ }^{\mathrm{a}}$ \\ ${ }^{a}$ Finnish Forest Research Institute, Rovaniemi Research Station, Box 16, FIN-96301 Rovaniemi, Finland \\ bInstitute of Biology, Kommunisticheskaya street 28, Syktyvkar 167610, Komi Republic, Russia
}

Received 24 October 2001; accepted 9 March 2002

\begin{abstract}
"Capsule": Satellite image analysis was effective in detecting anthropogenic changes in vegetation around an industrial center.
\end{abstract}

\begin{abstract}
In this paper we present what kind of human impacted changes can be found in dwarf birch (Betula nana) dominated shrub tundra vegetation around the large industrial complex of Vorkuta in the north-European Russian tundra. Using fieldwork data and Landsat TM satellite image we could identify two impact zones: (1) Pollution zone $\left(150-200 \mathrm{~km}^{2}\right)$. In this zone most of the lichen species are absent. Changes in vegetation communities' species composition in all main plant groups are obvious. Willows especially are more dominant than in the unpolluted sites. (2) Slight pollution/disturbance zone $\left(600-900 \mathrm{~km}^{2}\right)$. Here vegetation changes are mainly similar but less so than the changes in the first zone. Particularly, the amount of herbs and grasses is increased when compared to unpolluted areas. The pollution zones are spatially connected to the main emission sources in the area. Zones spread furthest to the northeast, matching the prevailing winds during winter. (C) 2002 Elsevier Science Ltd. All rights reserved.
\end{abstract}

Keywords: Arctic regions; Pollution; Vegetation changes; Remote sensing; Landsat TM

\section{Introduction}

The Vorkuta region is the largest industrial center in the north-European Russian tundra (Fig. 1a). It consists of the main city, and more than 10 sub-centers located near coal mines and other industrial units (Fig. 1b). The city and the first coal mines were established in 1930s. In the late 1950 s the population in the region increased quickly from 30000 in the early 1950 s to over 180000 in 1960s (Anonymous, 1990). Since 1960 the population in the region increased more steadily to 216000 in 1991. By 1999 it had declined to 172000 (Anonymous, 1990, 1999a). During the late 1950s and the 1960s there was rapid industrial development. Coal production continued to increase during the 1970s, and the total annual coal production in Vorkuta reached more than 20 million tons in the 1980s. Production declined rapidly in 1991 to 10 million tons, after which annual production

* Corresponding author. Tel.: +358-16-3364404; fax: +358-163364640 .

E-mail address: tarmo.virtanen@metla.fi (T. Virtanen). has been 12-15 million tons per year (Anonymous, 1999b).

Atmospheric pollution in the area is mainly caused by dust from open coalmines, emissions from coal combusting power plants and a cement factory, and burning of the waste rock near the coalmines. Emission data available from the 1990s suggest that output from the Vorkuta industrial complex is the highest in the Komi Republic, averaging 40000 tons per year (Anonymous, 1999c). This annual emission was $20-40 \%$ of that from the Severonikel' copper-nickel smelter in Monchegorsk in Kola Peninsula during the same period (Hagner and Rigina, 1998; Solovieva et al., in press), and only c. $2 \%$ compared with the annual emission from Norilsk (Toutoubalina and Rees, 1999). There are no reports of heavy metal emissions in the Vorkuta region, but since there are no metal smelters, it is reasonable to assume that these are much lower than those from Monchegorsk and Noril'sk.

During recent years several remote sensing studies have documented the drastic vegetation degradation around the metal smelters of the Kola Peninsula and 


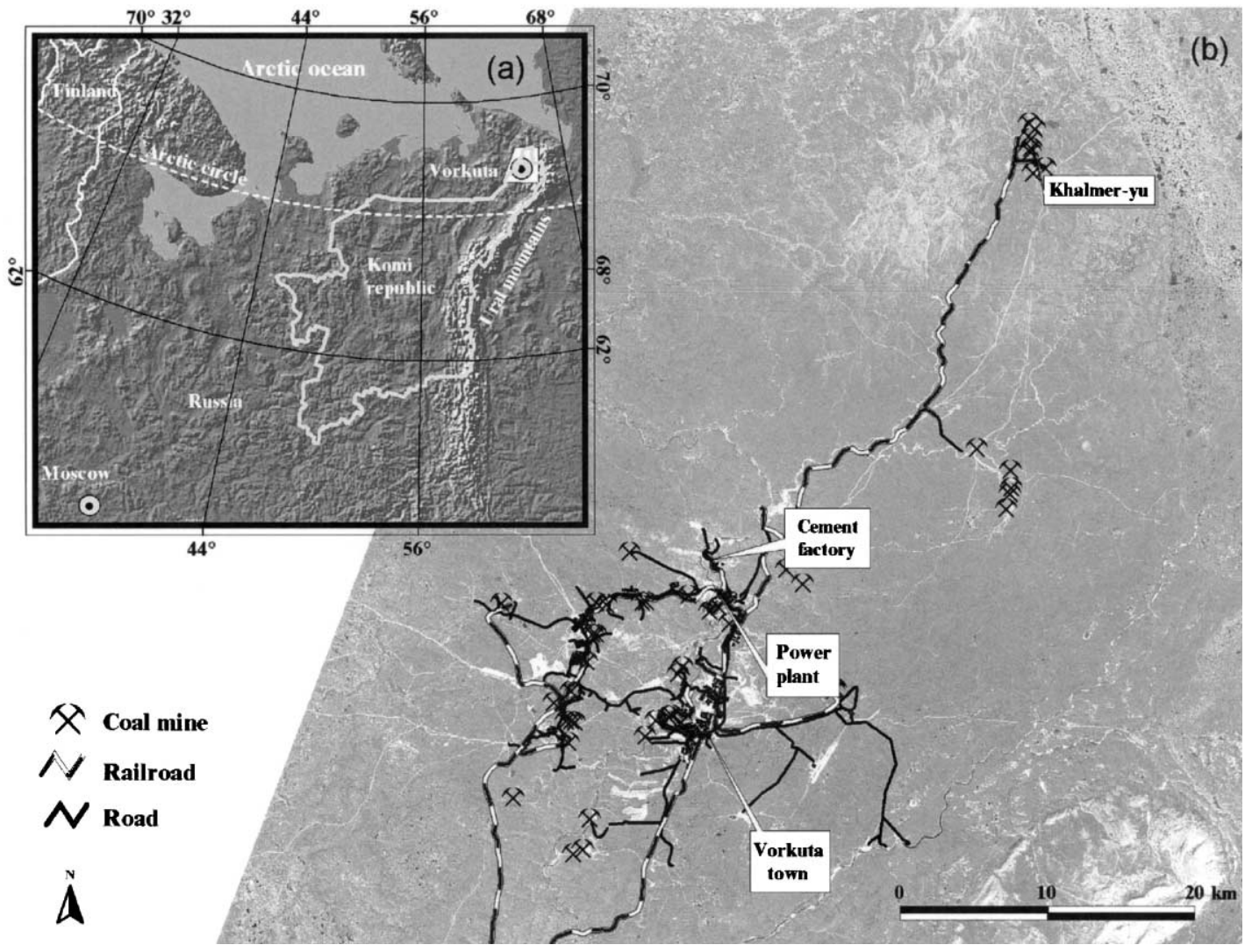

Fig. 1. (a) Location of the industrial complex of Vorkuta. White polygon shows study area. (b) More detailed view of the Vorkuta region. Railroads, roads, main cities, main emission sources, and coal mines are indicated. Some of the indicated mines have been abandoned during 1990s. The background is a Landsat TM 5 image, channel 3.

Noril'sk (Mikkola, 1996; Rees and Williams, 1997; Hagner and Rigina, 1998; Toutoubalina and Rees, 1999; Saich et al., 2001). The present study has its roots in the Landsat TM image mosaic based vegetation classification of the river Usa catchment. Vorkuta is located in the northeastern corner of this catchment. This classification was part of the EC-funded TUNDRA (Tundra Degradation in the Russian Arctic) research project. We collected ground truth data from different vegetation types in pristine areas in different parts of the Usa basin in the summers of 1998 and 1999. During classification we noticed that several spectral classes only occurred in the areas around the city of Vorkuta and were clearly spatially connected to the local industrial activities. In particular, areas that normally would have shrub tundra seemed to have spectral characteristics not found in other ground truth sites. However, these spectral signals did not indicate degradation of the green biomass, as is the case around the smelters in Kola and Noril'sk (Mikkola, 1996; Rees and Williams, 1997; Hagner and Rigina, 1998; Toutoubalina and Rees, 1999). Accordingly, in the summer of 2000 we undertook further ground truthing to describe and quantify the actual vegetation changes in the Vorkuta region.
Studies on man-induced changes in vegetation around the industrial complex of Vorkuta have not appeared previously in international journals. However, some Russian scientists have worked on this subject. Early descriptive studies of the tundra plant communities in the Vorkuta region were conducted in the 1930s and 1940s (Andreyev, 1936; Savich, 1940; Ruoff, 1946; 1947), and more recent studies have been made by, for example, Ruoff (1960), Khantimer (1974), and Rebristaya (1977). The first studies of the anthropogenic influence on vegetation in the Vorkuta region were carried out in 1976-1978 (Kuliyev, 1977, 1979; Kuliyev and Lobanov, 1978). They showed the extent of the pollution by analysing the concentration of particles in snow in different parts of the region and related these to the vegetation in corresponding sites during the summer. They produced a rough map, in which the Vorkuta area was divided into different pollution zones. In the "relatively clean"-zone the vegetation had not changed. In the zones of "small", "medium", and "high" pollution, the sensitive lichen species were absent, with more species being absent in the more polluted areas. Conversely, the quantity of some mosses had increased, and in the more polluted areas the abundance of grasses had also increased, compared to the sites in the unaffected 
tundra. The "maximum pollution" zone was found around the cement factory. Here lichens were totally absent, and the quantity of mosses and grasses was abnormally high. More detailed studies of the anthropogenically modified plant communities and vegetation dynamics in the area were made later by Druzhinina (1985) and Druzhinina and Myalo (1990). The effects of emissions to the different tundra ecosystem components were further studied during the 1990s (for example, Getsen et al., 1994; Shapiro and Ravinskaya, 1996; Grunina and Ovsova, 1996). These recent studies have more thoroughly described the changes whose main patterns were already described in the 1970s.

In the present article we report which kind of human impacted shrub tundra zones can be recognized by supervised classification of the Landsat TM image in the vicinity of the Vorkuta industrial complex. Remote sensing is a particularly useful monitoring technique in this region, because there are no car driveable roads outside the industrial complex (Fig. 1b), and thus the possibilities for extensive ground survey are limited. We compare our satellite image classification based estimates of the human impacted tundra areas with the results of the earlier field survey based studies on pollution effects. We also compare our observed changes in plant communities with those reported earlier by Russian researchers. Finally we discuss the possible mechanisms behind the changes, and briefly review the suggestions and conclusions presented in the Russian literature.

\section{Materials and methods}

\subsection{Study area}

The city of Vorkuta is located in the northwest Russian tundra, $67^{\circ} 30^{\prime} \mathrm{N}, 64^{\circ} 03^{\prime} \mathrm{E}$. The topography in the region is relatively smooth. Elevation varies from about $100 \mathrm{~m}$ a.s.l in the deepest river valleys to about $250 \mathrm{~m}$ at top of the smooth hills; typically elevation is between 150 and $200 \mathrm{~m}$. The Polar Ural mountains are located about $80 \mathrm{~km}$ east of the city of Vorkuta. The valley floors in these mountains have elevations of $200 \mathrm{~m}$ or more, and most of the mountain tops are $600-900 \mathrm{~m}$ a.s.l., while the highest points reach over $1200 \mathrm{~m}$. Mean temperatures in January are approximately $-21^{\circ} \mathrm{C}$, and in July $+12{ }^{\circ} \mathrm{C}$ (Anonymous, 1997). The area belongs to the permanent permafrost zone.

The coniferous treeline formed by spruce (Picea obovata Ledeb.) is located about $80 \mathrm{~km}$ south of Vorkuta. Dwarf birch (Betula nana L.) dominated shrub tundra is the most common vegetation type in the region, and is typically found in better drained and slightly elevated sites. Later in this article we refer to this vegetation type as "tall shrub tundra". This tundra type is characteristic to the north-eastern corner of the Usa basin. Further west, away from the Ural mountains lower shrub species (Vaccinium spp., Empetrum sp., etc.) dominate the shrub tundra (Andreyev, 1936; Rebristaya, 1977; personal observations). The predominance of dwarf birch in this region is probably due to the higher precipitation and related thick snow cover in the Vorkuta region due to the proximity of the Urals. Willow-dominated, often paludified, vegetation occurs in depressions. In this vegetation type many Sphagnum- and Carex-species are common, but ground lichens and typical drier site shrubs (for example, Empetrum nigrum L. and Vaccinium vitis-idaea $\mathrm{L}$.) are missing.

\subsection{Fieldwork and statistical analysis of field data}

Ground truthing around Vorkuta was undertaken in late July 2000 . We established ground truth plots in tall shrub tundra sites, or microtopographically comparable sites. Sites were selected in SW and NE directions from the industrial complex, some in roadless areas, which were reached using an all-terrain vehicle. Additional plots were established near roads. In the summer of 2000 the total number of sites examined was 26 . Furthermore, eight tall shrub tundra sites near the Polar Ural mountains were examined in 1999 and used as additional ground truth data; these were reached using the helicopter. Site locations are shown in Fig. 4. Sites were localized and marked on satellite image printouts in the field. At each site we estimated the percentage cover of different vegetation growth forms and the most common species and species groups in three circular plots (10 m diameter), situating $30 \mathrm{~m}$ apart from each other in a $\mathrm{S}-\mathrm{N}$ direction. The percentage cover was estimated by looking vertically downward on plots. We analysed vegetation coverage differences between four different pollution and/or disturbance levels (presented in Section 3) by analysis of variance using Proc GLM (SAS, 1990). In the analyses we used site-specific means calculated from three circles measured from every site. Coverage proportions were arcsin-transformated to normalize distributions. Pairwise comparisons were performed using Tukey's test for all coverage types which significantly differed between impact levels.

Within each ground truth site the dominant species (covering at least $5 \%$ of the area) composition was determined in four $0.5 \times 0.5 \mathrm{~m}$ quadrats. These were placed $5 \mathrm{~m}$ from the center of each middle circle and along each cardinal direction. At each quadrat we estimated the percent cover and the mean height of the dominant species. In addition, phytomass samples were collected from most of the plots (all living vascular plants, cut above the moss/lichen layer). Their dry weight was determined in the laboratory. Phytomass differences between different impact areas were analyzed using the analysis of variance. 


\subsection{Satellite image classification}

The analyzed Landsat TM 5 image (path 166, row 13) was acquired on 31 July 1988. It was georeferenced and rectified to UTM coordinates using Russian 1:200000 digital topographic maps as reference data (data source: GOSGISCENTER, Moscow). All seven channels were used in the supervised classification. Maximum likelihood decision rule was used, as it is generally used in this type of classifications, and it gave the most homogenous classes. Spectral signatures for the different pollution-modified types of tall shrub tundra were derived using ERDAS IMAGINEs interactive seed pixel tools by creating representative samples around field plots (ERDAS Field Guide, 1997). For the classification, these pollution signatures were combined to two classes, polluted and disturbed/slightly polluted. For vegetation and land cover types other than tall shrub tundra, we used spectral signatures developed for classification on the basis of the TUNDRA programme fieldwork, which was carried out in different parts of the Usa river basin during the summers of 1998, 1999 and 2000.
Information on this larger-scale study will be published elsewhere, but is also available on request from the authors.

\section{Results}

\subsection{Observed vegetation changes}

On the basis of the field observations of the vegetation composition, we classified ground truth sites according to their signs of pollution and/or human impact using the following classes: (1) no impact, (2) emission caused eutrophication/slight mechanical disturbance (for example, old once driven vehicle tracks), (3) minor pollution impact, (4) major pollution impact. Fig. 2a-d present examples of differently affected shrub tundra vegetation in the region. The percentage cover of different vegetation types in the impacted study sites are presented in Fig. 3, and tests of the statistical significance of the differences between impact levels are presented in Table 1 .

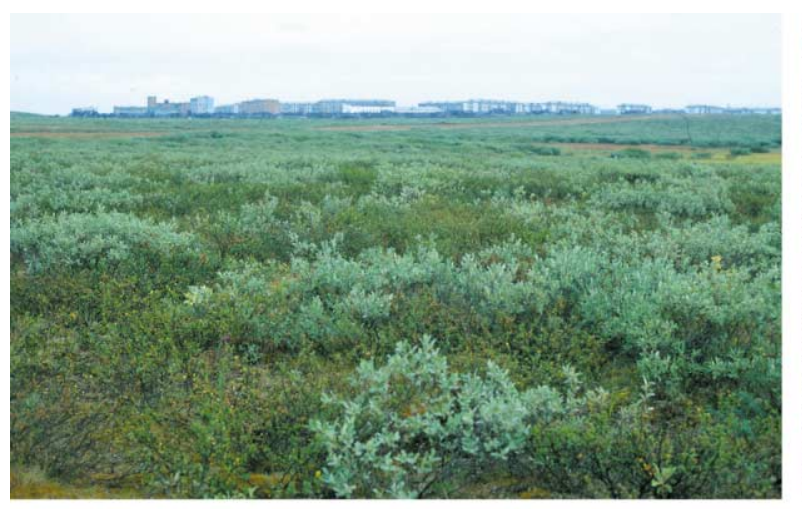

(a)

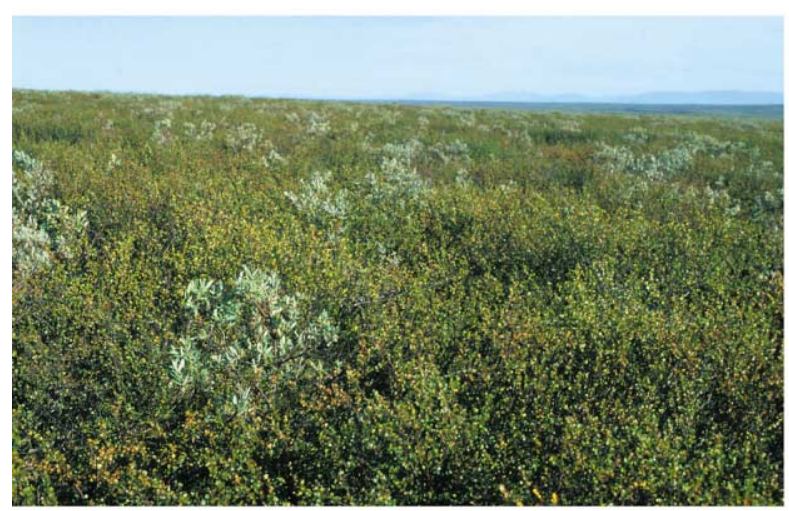

(c)

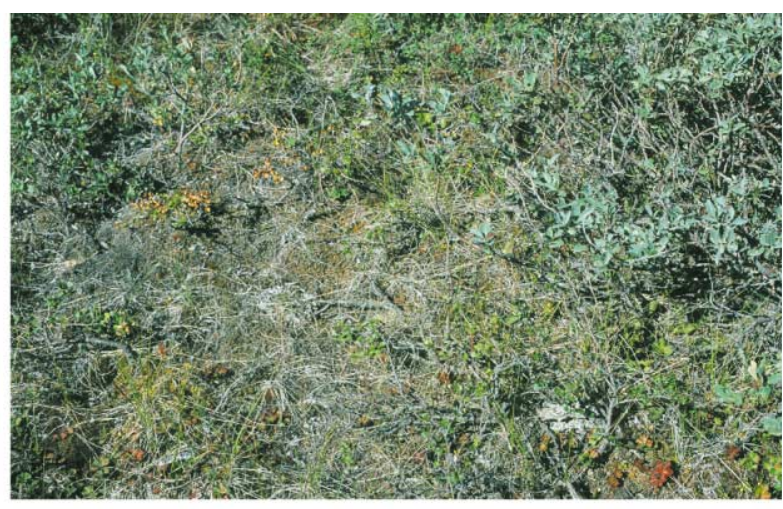

(b)

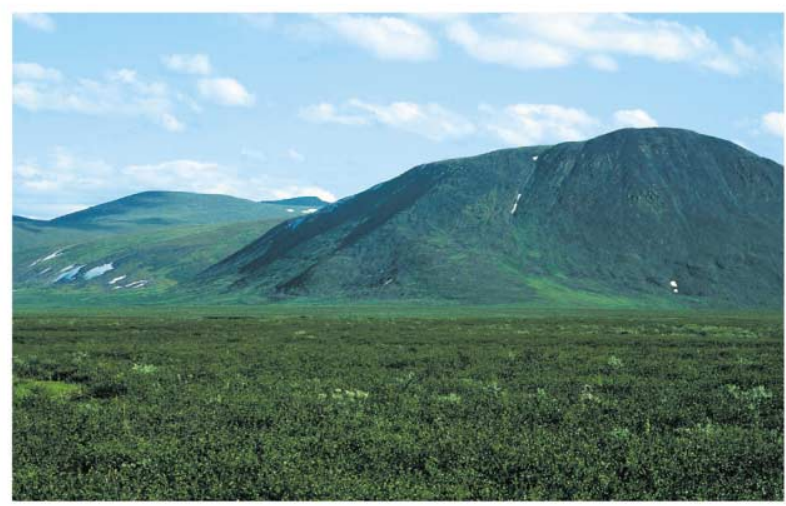

(d)

Fig. 2. (a-d) Examples of tall shrub tundra vegetation in the Vorkuta region. (a) Within the pollution zone, about $4 \mathrm{~km}$ southwest from the cement factory, the willows (gray leaved bushes) are more dominant than in pristine sites. In the background the settlement of Yurshor. (b) Closer view to vegetation in pollution zone, about $3 \mathrm{~km}$ northwest from the cement factory. There are no lichens, willows are more abundant than dwarf birches, and some unleaved, possibly dead shrubs are found. (c) Pristine tall shrub tundra, about $27 \mathrm{~km}$ northeast from the cement factory. (d) Pristine tall shrub tundra, near Polar Ural mountains, about $75 \mathrm{~km}$ northeast from the city of Vorkuta. Photographed by T. Virtanen in late July 2000 (a-c) and 1999 (d). 


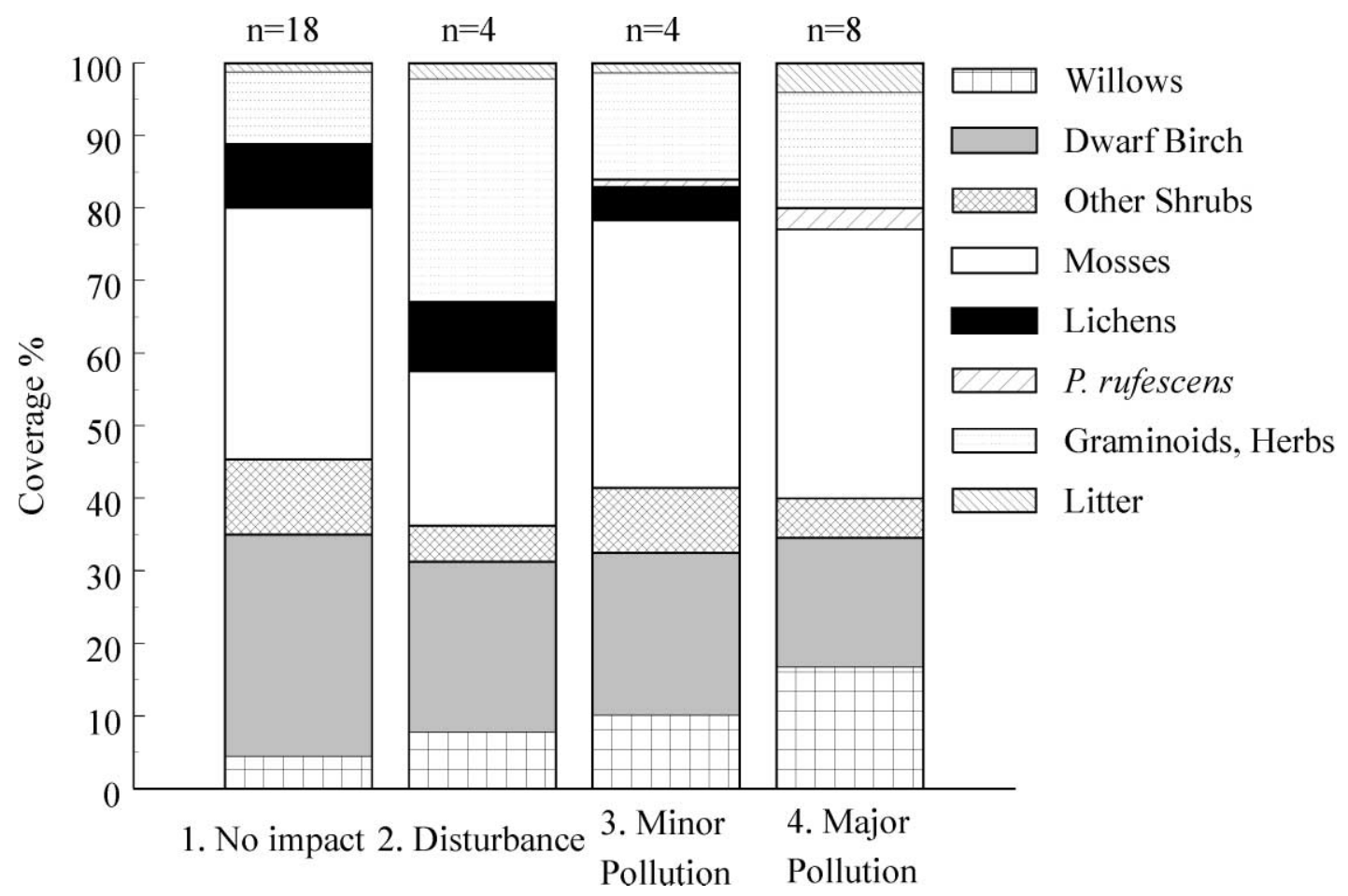

Fig. 3. The mean percentage cover of different growth forms and some species in field sites by human impact classes. $N$ is the number of measured sites. All site values are the mean values of three estimated circular plots $(r=5 \mathrm{~m})$.

In the area of no impact, the shrub layer of the typical tall shrub tundra is dominated by dwarf birch: it covers c. $20-50 \%$ of the area, and is c. $0.2-0.6 \mathrm{~m}$ in height. Some willow species (Salix spp., mainly gray leaved species, usually not taller than dwarf birches) are present, but usually do not cover more than $5 \%$ of the area. Lower dwarf shrubs (Vaccinium spp., and to a lesser extent species of Arctostaphylos, Empetrum, Ledum, etc.) usually cover c. $10 \%$ of the area, mosses (e.g. species of Pleurozium, Hylocomium, Dicranum) c. 20-40\%, and herbaceous plants (Festuca spp., Calamagrostis spp., Carex spp., many herbs) 5-15\%. Lichen cover (e.g. species of Cladonia, Cetraria, Stereocaulon, Peltigera, Nephroma) varies from c. $20 \%$ to almost $0 \%$. This variation is caused largely by variation in reindeer grazing intensity. There is no reindeer herding within the main industrial region, but in the other parts of the region it can be observed that lichens are grazed intensively, especially in areas near the Polar Ural mountains (Crittenden, 2000; personal observations). Comparing the amount of lichens in non-impacted areas near the Urals and elsewhere (presented together in Fig. 3), the Ural sites have lichen cover in the average of only $3.1 \%(n=8)$, whilst at the other sites the average cover is $13.3 \%(n=10)$. The percentage coverages of the other vegetation types near the Urals are relatively similar to those in other non-impacted areas.

When moving from pristine to human impacted areas, the percentage cover of willows increases from c. $4 \%$ to c. $17 \%$ and the coverage of dwarf birch drops from over
$30 \%$ to c. $18 \%$, and the coverage of the willows is significantly higher in both pollution levels than in pristine areas (Fig. 3, Table 1.). At the same time the cover of dwarf birch and other shrubs decreases from c. $40 \%$ to $20-25 \%$. Lichens are completely absent in the areas subject to major pollution impact, and their abundance is also reduced in areas subject to minor pollution. Exceptions are the lichen species Peltigera rufescens (Weiss) Humb., and the less abundant Leptogium saturnium (Dicks.) Nyl., which are found significantly most in the main pollution zone. In unpolluted areas these species are very rarely found (Fig. 3, Table 1). The quantity of grasses, sedges and herbs is highest in slightly mechanically disturbed and/ or eutrophied sites (over $30 \%$ cover), and is also increased significantly in polluted sites (16 and 15\%), when compared to non-impacted areas $(10 \%$; Fig. 3, Table 1). The coverage of mosses is significantly lowest in disturbed and/or eutrophied sites than in any other sites (Fig. 3, Table 1). Furthermore, several untypical or not so common tundra species are commonly found in eutrophied/slightly mechanically disturbed areas; most are typical early succession graminoid or herb species, such as Festuca ovina L., Calamagrostis lapponica (Wahl.) Hartm., and Epilobium angustifolium L.; these species are known to invade previously vegetated sites after disturbance, e.g. by fire or off-road traffic (Druzhinina, 1985).

There were no statistically significant differences between disturbance classes in mean aboveground 
Table 1

ANOVA-analysis of the coverage differences of the different growth forms and some plant species in different impact levels

a) Willows

$F_{3,30}=13.68, P<0.0001$

Tukey's pairwise comparison test:

\begin{tabular}{l|lll} 
& $\mathbf{2}$ & $\mathbf{3}$ & $\mathbf{4}$ \\
\hline $\mathbf{1}$ & - & $* * *$ & $* * *$ \\
$\mathbf{2}$ & & - & - \\
$\mathbf{3}$ & & & -
\end{tabular}

b) Dwarf birches

$F_{3,30}=9.33, P<0.0002$

Tukey's pairwise comparison test:

\begin{tabular}{l|lll} 
& $\mathbf{2}$ & $\mathbf{3}$ & $\mathbf{4}$ \\
\hline $\mathbf{1}$ & - & - & $* * *$ \\
$\mathbf{2}$ & & - & - \\
$\mathbf{3}$ & & & -
\end{tabular}

c) Other shrubs

$F_{3,30}=1.84, P>0.161$

d) Mosses

$F_{3,30}=5.60, P<0.0036$

Tukey's pairwise comparison test:

\begin{tabular}{l|lll} 
& $\mathbf{2}$ & $\mathbf{3}$ & $\mathbf{4}$ \\
\hline $\mathbf{1}$ & $* * *$ & - & - \\
$\mathbf{2}$ & & $* * *$ & $* * *$ \\
$\mathbf{3}$ & & & -
\end{tabular}

e) Lichens

$F_{3,30}=7.04, P<0.0010$

Tukey's pairwise comparison test:

\begin{tabular}{l|lll} 
& $\mathbf{2}$ & $\mathbf{3}$ & $\mathbf{4}$ \\
\hline $\mathbf{1}$ & - & - & $* * *$ \\
$\mathbf{2}$ & & - & $* * *$ \\
$\mathbf{3}$ & & & -
\end{tabular}

f) Peltigera rufescens

$F_{3,30}=24.16, P<0.0001$

Tukey's pairwise comparison test:

\begin{tabular}{l|lll} 
& $\mathbf{2}$ & $\mathbf{3}$ & $\mathbf{4}$ \\
\hline $\mathbf{1}$ & - & $* * *$ & $* * *$ \\
$\mathbf{2}$ & & - & $* * *$ \\
$\mathbf{3}$ & & & $* * *$
\end{tabular}

g) Graminoids and herbs

$F_{3,30}=9.48, P<0.0001$

Tukey's pairwise comparison test:

\begin{tabular}{l|lll} 
& $\mathbf{2}$ & $\mathbf{3}$ & $\mathbf{4}$ \\
\hline $\mathbf{1}$ & $* * *$ & - & - \\
$\mathbf{2}$ & & $* * *$ & $* * *$ \\
$\mathbf{3}$ & & & -
\end{tabular}

h) Litter

$F_{3,30}=1.91, P>0.14$

Tukey's test tables for pairwise comparison of the different impact levels are presented, when significant overall differences are found: $* * *=$ significant difference $(P \leqslant 0.05),-=$ no significant difference $(P \geqslant 0.05)$. Impact levels are as in Fig. 3; 1: No Impact, 2: Disturbance/Eutrophication, 3 : Minor pollution, 4: Major Pollution.

vascular plant phytomass $\left(F_{2,20}=0.09, \quad P>0.9\right.$; eutrophication/mechanical disturbance and minor pollution site observations were grouped due to the low number of observations in these classes). The mean dry phytomass at non-impacted sites was $371 \mathrm{~g} / \mathrm{m}^{2}$ (range 154-1036, $n=12$ ), in eutrophication/mechanical disturbance and minor pollution sites $333 \mathrm{~g} / \mathrm{m}^{2}$ (range 284$399, n=4)$. In major pollution sites the mean value was $341 \mathrm{~g} / \mathrm{m}^{2}$ (range $252-448, n=8$ ). Natural variation in phytomass within the non-impacted zone was sufficiently high to cover all the observed impacted area values. This large variation was principally due to intersite differences in the height of dwarf birch. We conclude that the modifications to plant communities in shrub tundra around Vorkuta have no obvious effect on the phytomass component of the local carbon cycle, which is one of the main research themes in the TUNDRA-project.

An additional observation during fieldwork was that willow leaves near the major pollution sources, but not in other areas, were intensively consumed by leaf beetles (Melasoma lapponica L.). This same beetle is known to undergo intensive outbreaks on willows in polluted areas on the Kola Peninsula (Zvereva et al., 1995; Zvereva and Kozlov, 2000).

\subsection{Satellite image classification}

In the Landsat TM image classification we separated two different impact zones (Fig. 4a and b). 


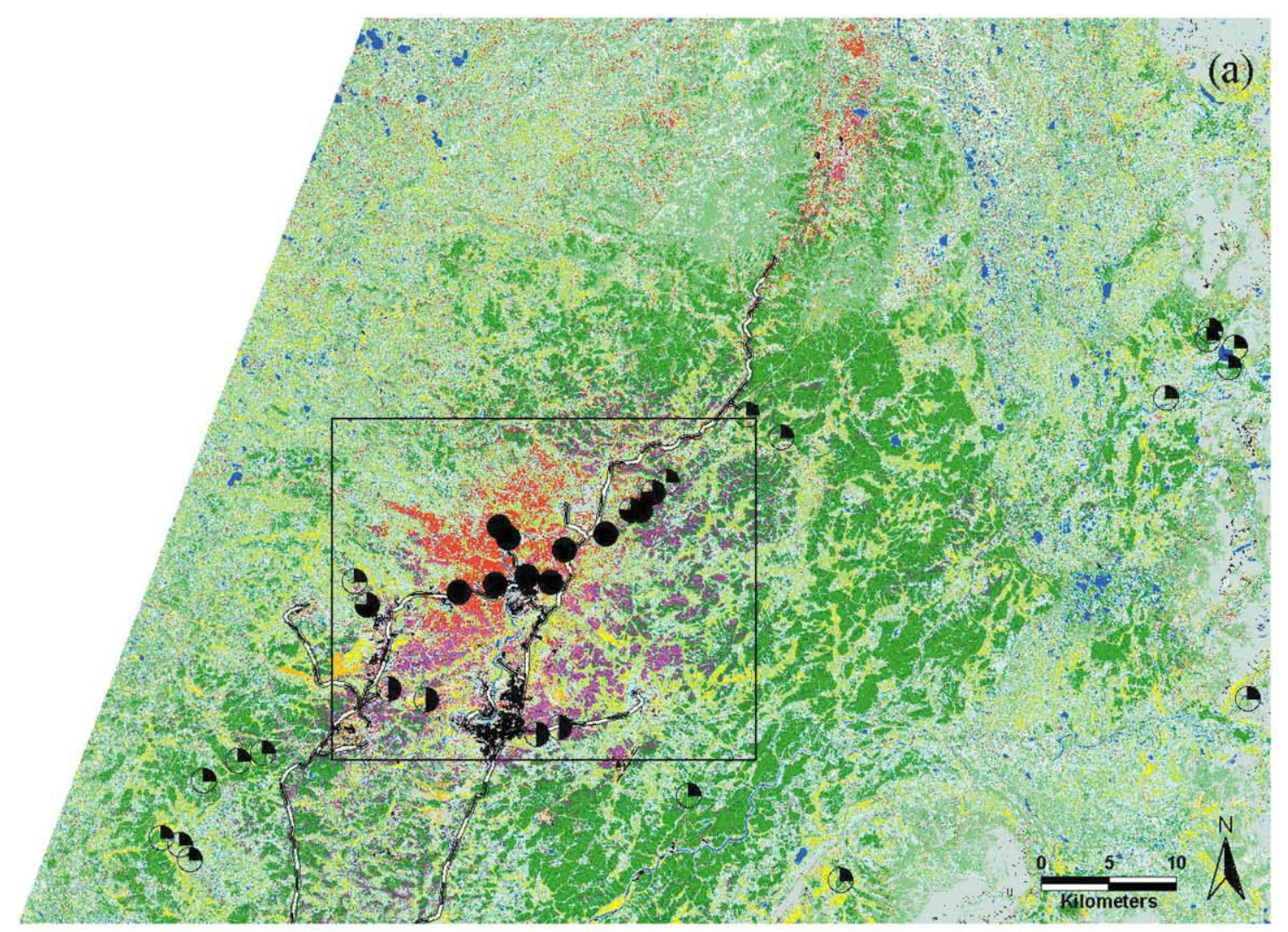

Field plots (disturbance class)
Non-impacted
Disturbed
Minor pollution
Major pollution
Railroad

Polluted
Disturbed
Tall shrub tundra
Willows complex
Low shrub tundra
Lichen tundra
Meadow
Wetlands
Bare soil, rock
Water
Fields
Urban

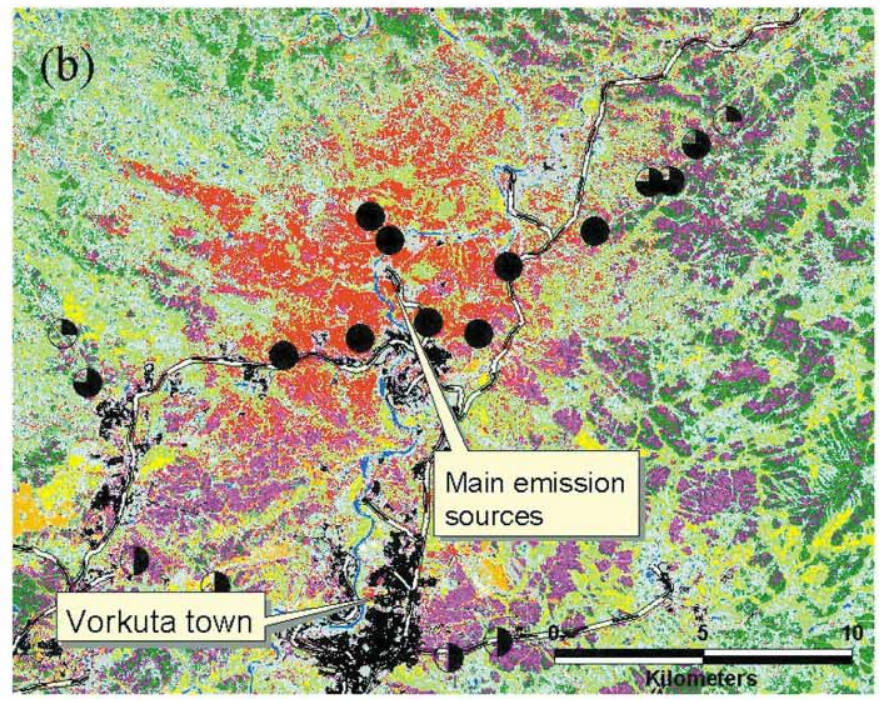

Fig. 4. Satellite image classification for the Vorkuta region. (a) Classification for the whole region, (b) more detailed view of the industrialised area. Differently impacted ground truth sites are indicated with differently filled circles.

\subsubsection{Pollution zone}

This is caused by emissions from the two main air pollutant sources in the area: a cement factory and the near situating power plant. These are located about 15 $\mathrm{km}$ north of the city of Vorkuta. Ground truth points in class 4, major pollution, are within this zone. Here lichens (other than $P$. rufescens and $L$. saturnium) are missing and willows are more dominant than in unpolluted areas. In some sites in this zone there was greater occurrence of damaged or dead parts in dwarf shrubs, and dead patches in mosses, than in non-impacted areas. However, generally the moss layer appeared even thicker than in pristine areas. Vegetation is also to some extent covered by emitted dust. The area in Vorkuta region that is clearly affected by pollution, including all vegetation and land use classes, is approximately 150 $200 \mathrm{~km}^{2}$. This vegetation type continues as a $200-1000$ $\mathrm{m}$ wide corridor around the railroad to the coalmine 
town of Khal'mer-Yu, around which there is another affected area of $50-100 \mathrm{~km}^{2}$.

\subsubsection{Slight pollution/disturbance zone}

Changes in vegetation here have some similarities but are slighter than the changes in the strong pollution zone. Furthermore, grasses and herbs are more common in this zone. Ground truth points in impact classes 2 and 3 belong to this zone. The extent of this area around Vorkuta is about $600-900 \mathrm{~km}^{2}$ (including the pollution zone 1).

\section{Discussion}

\subsection{Impact area indicated by satellite image classification}

The human impact zones identified in the satellite image classification (Fig. 4a and b) correspond in general to the observations presented in the earlier Russian studies. Unfortunately we cannot present any numerical tests of the classification accuracy, because it was not possible to obtain independent test data due to limited possibilities of the fieldwork. It is also clear that the categorization of this kind of continuum is arbitrary. Nevertheless, satellite image classification adds new spatial details to the knowledge of vegetation changes, since earlier studies were based solely on relatively scarce field observations.

It is clear that the sites most affected by pollution in the Vorkuta region are found around the main emission sources, i.e. the cement factory and the power plant (Kuliyev, 1977; Kuliyev, 1979; Druzhinina, 1985; Druzhinina and Myalo, 1990; Getsen et al., 1994; personal field observations). In the Vorkuta region the prevailing winds blow from the southwest and south from September to April (Anonymous, 1997). From May to August the wind direction is relatively variable, but the most frequent wind directions are from the north and northwest (Anonymous, 1997). In accordance with the prevailing winter winds, the area with the highest concentration of dust particles in snow was found in the northeast of the main emission sources (Kuliyev and Lobanov, 1978). Correspondingly, the inner pollution zone in our classification extends furthest to the northeast direction from the main emission sources. A zone of slight pollution/disturbance can be found around most of the mines and settlements, but again there is a tendency for the areas to be extended eastwards more than in other directions. Increased concentrations of elements in the environment due to emissions can be found much further than our impact zones indicate. For example, the quantities of spheroidal carbonacoeus particles (only produced from high temperature combustion) in lake sediments and sulphate concentrations in snow were above background values (i.e. those in the non-impacted parts of the Usa basin) as far as about 70 $\mathrm{km}$ east from Vorkuta (Solovieva et al., 2002, in press; Walker et al., submitted for publication).

We have shown that even non-destructive man induced changes in tundra vegetation communities, expressed by changes in species composition, can be detected using Landsat TM image analysis. In this case their detection was relatively straightforward for several reasons. First, the relatively smooth topography in the region minimized shadow effects in the satellite image due to relief differences. Second, the lack of trees and their shadows allowed a non-disturbed view to the field layer. Third, there is a clear difference in leaf color between dark green colored dwarf birches that were partly replaced in impacted areas by gray leaved willows. Fourth, the gray cement dust contributed to the spectral signal and probably helped the classification of the strong pollution zone. The dust cover of plants in the areas of intense deposition is so extensive within a few kilometers from the cement factory that it probably changes the reflectance. However, we cannot see this as a major problem for the impact zone classification, because particulate deposition load and changes in plant communities are surely tightly spatially correlated.

The satellite image was acquired in late July 1988, while the present fieldwork was undertaken in late July 2000. Thus bias due to seasonal differences between the field results and spectral patterns in the satellite image should have been minimized. The 12 years time lag between the image acquisition and the fieldwork raises some questions about the reliability of the conclusions. However, virtually all man made structures (buildings, tracks etc.) encountered in the field were already present in the time the satellite image was acquired. Our field observations are also consistent with the results of earlier vegetation surveys in this region. Furthermore, studies made by Russian ecologists indicate that there have been no rapid alterations in vegetation composition during recent years. This might be at least partly due to the fact that pollution loads in the region 10-30 years ago were higher than at present (Solovieva et al., 2002 , in press). Since all mines in the Khal'mer-Yu and also some mines around Vorkuta are now closed, it is even probable that the vegetation recovery has already begun around those closed mines.

\subsection{Pollution loads and their effects to the soils}

For understanding these vegetation changes, we briefly review the results on the studies of the emission loads and their effects on the soils in the Vorkuta region. Getsen et al. (1994) have described soils in the most polluted sites in the Vorkuta, equivalent to our inner pollution zone. Here upper soil layers $(15-30 \mathrm{~cm})$ have become chemically modified with $\mathrm{pH}$ ranging from 
6.7 to 8.9 indicating strong alkalization, and concentrations of exchanging calcium and total nitrogen content are $10-20$ and $2-4$ times higher, respectively, than at comparable non-polluted sites. Heavy metal concentrations are also increased with values for $\mathrm{Cu}, \mathrm{Zn}, \mathrm{Cd}$ and Co being three times, six times, 15-20 times and 2-4 times, respectively, higher than the background values. However, this level of metal contamination is still much lower than in the surroundings of the Severonikel' copper-nickel smelter in Monchegorsk in the Kola Peninsula, where, for example, $\mathrm{Cu}$ and $\mathrm{Ni}$ concentrations in soil are over 300 and 100 times higher, respectively, than in background areas (Lukina and Nikonov, 2001). The amount of the particulate deposits in the snow in spring 1978 was approximately 8-40 times higher within the inner pollution zone indicated in our classification than in areas $15-20 \mathrm{~km}$ away from the main pollution sources (Kuliyev and Lobanov, 1978).

In the TUNDRA-project Walker et al. (submitted for publication, in preparation) have studied the extent of pollution in different parts of the Usa basin. Two of their 1999 sampling sites were 8 and $15 \mathrm{~km}$ from the main emission sources in Vorkuta, both sites falling within the slight pollution/mechanical disturbance zone in our classification. In these sites, Ca concentrations in snow were about 20 times higher than at more remote locations and the mean soil $\mathrm{pH}$ values were 5.7 and 6.8 , respectively. At sites within our non-impacted zone in the northeastern part of the Usa basin recorded soil $\mathrm{pH}$ values were ca. 5 , and in pristine regions usually below 4.5 (Walker et al., submitted for publication, in preparation). Metal concentrations in those same two sites in both soil and snow were approximately two $(\mathrm{Cu}, \mathrm{Ni}$, $\mathrm{Zn})$, five $(\mathrm{Pb}, \mathrm{Sr})$, or ten $(\mathrm{Al}, \mathrm{Ba})$ times higher than the background values.

\subsection{Vegetation changes and hypotheses about underlying mechanisms}

Our assessment of the vegetation changes around Vorkuta is generally in agreement with the key findings of previous Russian studies in the region (see section 1). We have divided hypotheses about the vegetation change mechanisms into three main groups, which will be discussed below. To evaluate hypotheses that explain observed vegetation changes, we also review some details found in previous studies that were not handled in our work.

\subsubsection{Direct injury effects}

Lichens are known to be sensitive to pollution, especially to $\mathrm{SO}_{2}$ (e.g. Seaward, 1993). Epiphytic lichens have been widely used in pollution mapping, as species sensitivity to pollutants varies (Seaward, 1993; Poikolainen et al., 2000; Conti and Cecchetti, 2001). The absence of the most of the terricolous lichen species near the main major pollution sources is proposed to be due to phytotoxic effects of pollutants (Getsen et al., 1994; Shapiro and Ravinskaya, 1996; Grunina and Ovsova, 1996; but see also Section 4.3.2). Slight increases in the amount of apparently damaged shrubs and mosses in the polluted areas can be caused by direct injuries, or, for example, potentially increased early summer frost damages due to earlier snow melting (see more in Section 4.3.3).

\subsubsection{Mechanical disturbance, fertilization}

Mechanically disturbed shrub tundra sites are typically invaded by grasses and sedges (Druzhinina, 1985; Druzhinina and Myalo, 1990; Forbes and Jeffries, 1999). Furthermore, experiments have shown that the abundance of grasses in shrub tundra communities quickly increases after fertilization (Jonasson, 1992; Parsons et al., 1995). It is known that alkaline dust causes a decrease in the abundance of Sphagnum mosses and most of the lichens, whereas the quantity of many mosses and grasses increases rapidly (Forbes, 1995; Auerbach et al., 1997). These types of vegetation changes (increased grass and herbs dominance, thickening of the moss layer) are reported from the Vorkuta region (Kuliyev, 1977, 1979; Druzhinina, 1985; Druzhinina and Myalo, 1990). Thus, these observations can be explained as consequences of fertilization by alkalization and/or additional nitrogen. From the region there is observations about both of these processes, alkalization and increase of the nitrogen content of the soils (Anonymous, 1991; Getsen et al., 1994).

Extensive grazing and trampling of reindeers can also cause substitution of the lichens and shrubs by graminoids, herbs and mosses (Väre et al., 1996; Crittenden, 2000). Reindeer herding is intensive in our study area outside the main industrial region. Signs of grazing were even more intensive near the Polar Urals than areas near Vorkuta, which indicates that reindeers are not the major factor behind the observed vegetation changes.

Kuliyev (1979) reported that the annual growth and size of willows (Salix lanata L.) and some herbaceous plants (Bistorta major S.F. Gray, Veratrum lobelianum Bernh.) was greater in the dust polluted areas compared to non-polluted areas. We believe that this observation can also be explained by fertilization hypothesis. Furthermore, such an increased growth of vascular plants might have negative effects on the abundance of terricolous lichens via competitive exclusion (Jonasson, 1992; Crittenden, 2000). Faster growing willows probably also can respond more quickly to increased nitrogen than the slower growing dwarf birches. Thus, observed replacement of the dwarf birches by willows could be potentially explained by competitive exclusion. However, Kuliyev's (1979) explanation for the increased plant growth was the longer growing period caused by 
earlier snow melt, which is one of the obvious consequences of heavy dust pollution.

\subsubsection{Effects related to earlier snow melting}

The fact that dust emissions causes earlier snow melt in the vicinity of Vorkuta is demonstrated by the image that we constructed on the basis of satellite data (Fig. 5). Areas in the lowland tundra with early snow melt are clearly spatially correlated with the main emission sources. The shape of the earlier snow-free areas around Vorkuta corresponds well with the isolines in snow dust cover mapped by Kuliyev and Lobanov (1978). Earlier snowmelt provides a longer growth period, but also increases the risk of frost injury, since dwarf birch prefers sites with thick sheltering snow cover. One potential factor contributing to the displacement of dwarf birch by willow could be a different frost sensitivity and, furthermore, possibly a differential ability to compensate for the damage. In the areas of earlier snowmelt, the permafrost should generally melt to a greater depth. However, the depth of this melting is dependent on the vegetation composition. If terrain becomes unvegetated, the depth of the active layer will increase due to better heat conductivity (Druzhinina and Myalo, 1990). Conversely, a denser vegetation cover, especially a thick moss-layer, retards permafrost melting (Kuliyev, 1979). It is not very obvious what would be the net effect of the potential man induced permafrost changes in shrub tundra in Vorkuta region. It is also unclear how these changes affect the local water table. Could increased moisture explain the dominance of willow?

\subsection{Conclusions and implications}

Our study shows that remote sensing is a particularly useful monitoring technique to study the extent of the human caused vegetation changes, especially in this kind of region with limited ground survey possibilities. We could recognize around the Vorkuta two different main impact zones. Vegetation changes in these zones are caused by a combination of factors leading to regionally and locally variable changes due to variation in the intensity of different processes in different localities.

The inner impact zone is a heavily dust-polluted area around the cement factory and the near locating power plant. It is seems that plant communities are clearly suffering in this zone: many plant species still survive well, but obvious pollution induced injuries can be found on some species, and the most pollution sensitive species are totally absent. Local people have also recognized this pollution, and are especially concerned its effects to peoples health (Karjalainen and Habeck, submitted for publication). However, this clearly pollution impacted area seems to be relatively small, and by more effective cleaning techniques the situation would be surely improved.

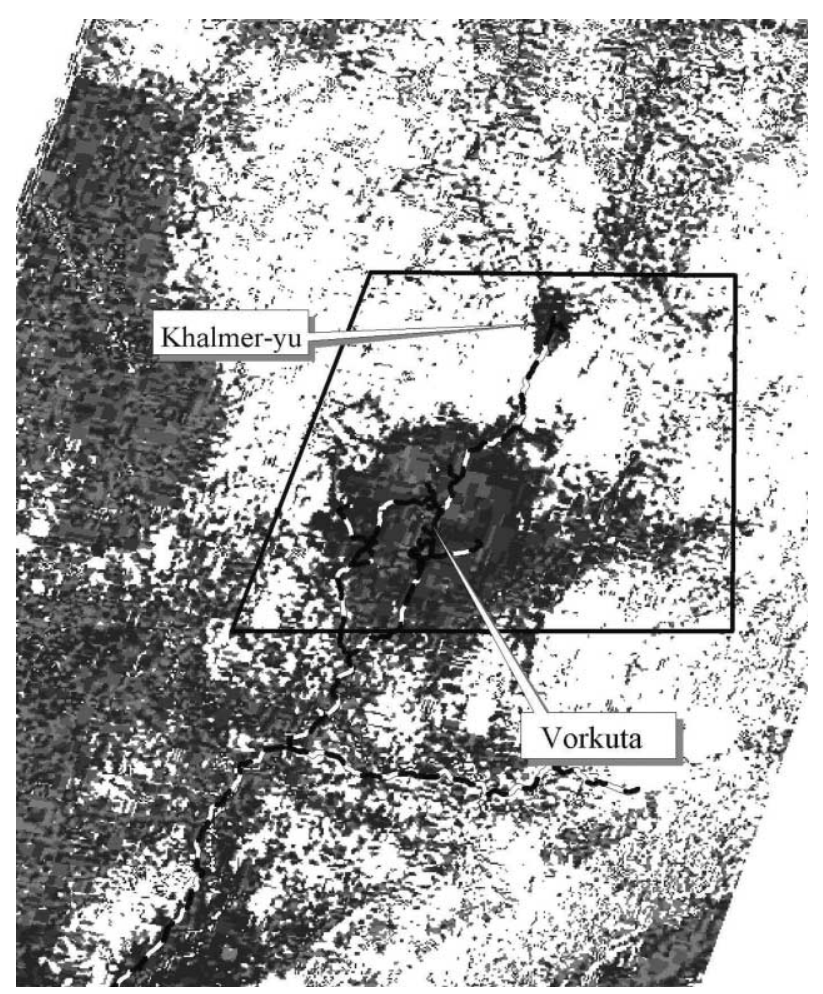

Fig. 5. A composite image of the Landsat previews from 20 June in 1985 , path 167 , rows 12 and 13. White areas are still covered by snow, gray and black areas are already exposed. Black polygon shows the study area. Railroad and cities are indicated. Source images are available in the web pages of Eurimage: http://www.eurimage.com/einet/ einet_home.shtml.

A larger impact area surrounds all the main industrial areas, where the species composition of plant communities is altered from climax phase communities to younger ones, but where no obvious pollution damage can be found. It is obvious that these types of changes in vegetation communities cannot be totally avoided if there exist any kinds of industrial activities in the tundra.

\section{Acknowledgements}

We would like to thank Peter Crittenden, Bruce Forbes, Joachim Otto Habeck, Viv Jones, Timo P. Karjalainen, Nadia Solovieva, Tony Walker and two anonymous reviewers for their constructive comments. This study is a part of the TUNDRA project, funded by the Environment and Climate Programme of the European Commission (contract ENV4-CT97-0522).

\section{References}

Andreyev, V.N., 1936. Rastitelnost' i prirodnye rayony vostochnoy chasti Bol'shezemel'skoy tundry [Vegetation and Natural Regions in the Eastern Part of the Bol'shezemel'skaya Tundra]. Trudy Polyarnoy komissii [Works of the Polar Commission] 22, 1-97. Leningrad (in Russian). 
Anonymous, 1990. Gorodskoye naseleniye Respubliki Komi [Urban population of Komi Republic]. Statisticheskiy otchet o perepisi naseleniya 1989 goda [Statistical Report based on the Census of 1989]. Gosudarstvennyy komitet Respubliki Komi po Statistike [State Committee of the Komi Republic for Statistics], Syktyvkar. (in Russian).

Anonymous, 1991. Atmosfernyye nagruzki zagryaznyayushikh veshchestv na territorii SSSR [Atmospheric Loadings of Pollutants on the Territory of the USSR]. Gidrometeoizdat, Moscow. (in Russian).

Anonymous, 1997. Atlas Respubliki Komi po klimatu i gidrologii [Atlas of the climate and hydrology of the Komi Republic]. Izdatel'skiy dom Drofa, Moscow. (in Russian).

Anonymous, 1999a. Naseleniye Respubliki Komi, 1991-1999 [Population of the Komi Republic, 1991-1999], Otchet Rossiyskogo statisticheskogo tsentra i Gosudarstvennogo komiteta Respubliki Komi po Statistike [Report of the Russian Centre for Statistics and State Committee of the Komi Republic for Statistics], Tsentral'nyy gosudarstvennyy Arkhiv [Central State Archive] (in Russian).

Anonymous, 1999b. Ugol'naya industriya SSSR v 1970-1999 gg. [Coal Industry of the USSR, 1970-1999]. Svodka yezhegodnykh otchetov Ministerstva ugol'noy promyshlennosti [Summary annual reports of the Ministry for coal industry]. Moscow (in Russian).

Anonymous, 1999c. Gosudarstvennyy doklad o sostoyanii okruzhayushchey prirodnoy sredy Respubliki Komi v 1999 godu [State Report on the State of the Natural Environment of the Komi Republic, 1999], Ministerstvo prirodnykh resursov i okhrany okruzhayushchey sredy Respubliki Komi [Ministry of Natural Resources and Environmental Protection, Komi Republic], Syktyvkar (in Russian).

Auerbach, N.A., Walker, M.D., Walker, D.A., 1997. Effects of road dust on substrate and vegetation properties in arctic tundra. Ecological Applications 7, 218-235.

Conti, M.E., Cecchetti, G., 2001. Biological monitoring: lichens as bioindicators of air pollution assessment - a review. Environmental Pollution 114, 471-492.

Crittenden, P.D., 2000. Aspects of the ecology of mat-forming lichens. Rangifer 20, 127-139.

Druzhinina, O.A., 1985. The vegetation dynamics in the intensively developed Far North regions. In: Chernov, Yu.I. (Ed.), Soobshchestva Kraynego Severa i chelovek [Communities of the Far North and Man]. Nauka, Moscow, pp. 205-231. (in Russian, with English Abstract).

Druzhinina, O.A., Myalo, E.G., 1990. Okhrana rastitel'nogo pokrova Kraynego Severa [The Protection of the Vegetation Cover of the Far North]. Agropromizdat, Moscow. (in Russian).

ERDAS Field Guide, fourth ed. 1997. Erdas Inc., Atlanta, Georgia.

Forbes, B.C., 1995. Tundra disturbance studies. III. Short-term effects of aeolian sand and dust, Yamal Region, Northwest Siberia, Russia. Environmental Conservation 22, 335-344.

Forbes, B.C., Jeffries, R.L., 1999. Revegetation of disturbed arctic sites: constraints and applications. Biological Conservation 88 , $15-24$.

Getsen, M.V., Stenina, A.S., Khokhlova, L.G., Rusanova, G.V., Ivanov, M.A., Maksimov, A.A., Patova, E.N., 1994. The condition of the environment of the Bol'shezemel'skaya tundra on the Vorkuta industrial region territory. Narodnoye khozyaystvo Respubliki Komi 3, 68-75. (in Russian with English Abstract).

Grunina, L.K., Ovsova, T.A., 1996. Biogennaya akkumulyatsiya azota, zol'nykh elementov i tyazhelykh metallov sporovymi v usloviyakh Bol'shezemel'skoy tundry [Biogenic accumulation of nitrogen, ashes elements and heavy metals by cryptogamic plants in conditions of the Bolschezemelskaya Tundra]. In: Lavrinenko, I.A. (Ed.), Nekotoryye podkhody k organizatsii ekologicheskogo monitoringa na territoriyakh dobychi $\mathrm{i}$ transportirovki nefti i gaza [Some Approaches to the Organization of Ecological Monitoring in
Territories of Oil and Gas Production and Transportation]. Komi Nauchnyy Tsentr [Komi Science Centre], Syktyvkar, pp. 40-49. (in Russian).

Hagner, O., Rigina, O., 1998. Detection of forest decline in Monchegorsk area. Remote Sensing of Environment 63, 11-23.

Jonasson, S., 1992. Plant responses to fertilization and species removal in tundra related to community structure and clonality. Oikos 63, $420-429$.

Karjalainen, T.P., Habeck, J.O., (submittedn. Environmental perception and awareness in local contexts: a case study from the north of the Komi Republic, Russia. Environmental Politicsfor publication).

Khantimer, I.S., 1974. Agricultural Development of Tundra. Nauka, Leningrad. (in Russian with English Abstract).

Kuliyev, A.N., 1977. The effect of the dust pollution to tundra vegetation in Vorkuta outskirts (the Eastern Part of the Bol'shezemel'skaya Tundra). In: Ye.Ye. Syroyechkovskiy (Ed.), Nauchnyye osnovy okhrany prirody [Scientific fundamentals of Nature Protection]. Moscow, pp. 22-28 (in Russian with English Abstr.).

Kuliyev, A.N., 1979. A study of the dust pollution effects to tundra vegetation in Vorkuta outskirts. In: Ye.Ye. Syroyechkovskiy (Ed.), Vliyaniye deyatelnosti cheloveka na prirodnyye ekosistemy [The Influence of Human Activities on Natural Ecosystems]. Moscow, pp. 60-66 (in Russian with English Abstract).

Kuliyev, A.N. and Lobanov, V.A., 1978. Distribution of dust pollution in Vorkuta outskirts. In: Ye.Ye. Syroyechkovskiy (Ed.), Vliyaniye deyatelnosti cheloveka na prirodnyye ekosistemy [The Influence of Human Activities on Natural Ecosystems]. Moscow, pp.81-89 (in Russian with English Abstract).

Lukina, N., Nikonov, V., 2001. Assessment of environmental impact zones in the Kola Peninsula forest ecosystems. Chemosphere 42, $19-32$.

Mikkola, K., 1996. A remote sensing analysis of vegetation damage around metal smelters in the Kola Peninsula, Russia. International Journal of Remote Sensing 17, 3675-3690.

Parsons, A.N., Press, M.C., Wookey, P.A., Welker, J.M., Robinson, C.H., Callaghan, T.V., Lee, A.J., 1995. Growth responses of Calamagrostis lapponica to simulated environmental change in the Subarctic. Oikos 72, 61-66.

Poikolainen, J., Kuusinen, M., Mikkola, K., 2000. Epiphytic lichens as indicators of air quality. In: Mälkönen, E. (Ed.), Forest condition in a changing environment - the Finnish case. Kluwer Academic Publishers, Netherlands, pp. 162-170.

Rebristaya, O.V., 1977. Flora of the Eastern Part of the Bol'shezemel'skaya tundra. Nauka, Leningrad (in Russian with English Abstract).

Rees, W., Williams, M., 1997. Monitoring changes in land cover induced by atmospheric pollution in the Kola peninsula, Russia, using Landsat MSS-data. International Journal of Remote Sensing $18,1703-1723$.

Ruoff, Z.F., 1946. Geobotanicheskaya kharakteristika osnovnykh tipov vorkutinskikh tundr [Geobotanical Characteristics of the Basic Tundra Types around Vorkuta]. Rukopisnyye fondy. Vorkutinskaya Nauchno-issledovatel'skaya Merzlotnaya Stantsiya [Manuscript funds of Vorkuta Permafrost Research Station] (in Russian).

Ruoff, Z.F., 1947. Geobotanicheskaya kharakteristika tipov tundry Vorkutinskogo rayona [Geobotanical Characteristics of Tundra Types in the Vorkuta Area]. Rukopisnyye fondy. Vorkutinskaya Nauchno-issledovatel'skaya Merzlotnaya Stantsiya [Manuscript funds of Vorkuta Permafrost Research Station] (in Russian).

Ruoff, Z.F., 1960. Tipy tundry v rayone Vorkuty i ikh svyaz' s mnogoletnemerzlymi porodami [Types of the Tundra in the Vorkuta Area and their Connection with Continually Frozen Rock Formations]. Trudy Severnogo otdeleniya Instituta merzlotovedeniya [Works of the Northern Department of the Permafrost Institute] 1, 147-168. Syktyvkar (in Russian). 
Saich, P., Rees, W.G., Borgeaud, M., 2001. Detecting pollution damage to forests in the Kola Peninsula using the ERS SAR. Remote Sensing of Environment 75, 22-28.

SAS, 1990. SAS/STAT user's guide, version 6, fourth ed. SAS Institute, Cary, NC.

Savich, V.M., 1940. Rastitel'nyy pokrov Vorkutinskogo Rudnichnogo rayona. [Plant cover of the Rudnik area in Vorkuta]. Rukopisnyye fondy. Vorkutinskaya Nauchno-issledovatel'skaya Merzlotnaya Stantsiya [Manuscript funds of Vorkuta Permafrost Research Station] (in Russian).

Shapiro, I.A., Ravinskaya, A.P., 1996. Vliyaniye atmosfernogo zagryazneniya $\mathrm{v}$ Vorkutinskom promyshlennom rayone na dykhanie i kletochnuyu aktivnost' lishaynikov [Influence of the atmospheric pollution in the Vorkuta Industrial Region on the respiration and cell penetrability of the lichens]. In: Getsen, M.V., Stenina, A.S., Voronin, L.V. (Eds.), Bioindikatsiya sostoyaniya prirodnoy sredy Vorkutinskoy tundry [Bioindication of the State of the Natural Environment in the Vorkuta Tundra]. Komi Nauchnyy Tsentr [Komi Science Centre], Syktyvkar, pp. 115-120. (in Russian).

Seaward, M.R.D., 1993. Lichens and sulphur dioxide air pollution: field studies. Environmental Reviews 1, 73-91.

Solovieva, N., Jones, V., Appleby, P., Kondratenok, B., 2002. Extent, environmental impact and long-term trends in air pollution in the
Usa basin of East-European Russian Arctic. Water, Air, and Soil Pollution (in press).

Toutoubalina, O.V., Rees, G.W., 1999. Remote sensing of industrial impact on Arctic vegetation around Noril'sk, northern Siberia: preliminary results. International Journal of Remote Sensing 20, 2979 2990.

Väre, H., Ohtonen, R., Oksanen, J., 1996. Effects of reindeer grazing on understorey vegetation in dry Pinus sylvestris forests. Journal of Vegetation Science 6, 523-530.

Walker, T.R., Young, S.D., Crittenden, P.D. and Zhang, H. Anthropogenic metal enrichment of snow and soil in Northeastern European Russia. Environmental Pollution (submitted for publication).

Walker, T.R., Crittenden, P.D. and Young, S.D. Regional variation in the chemical composition of winter snowpack and terricolous lichens in relation to sources of acid emissions in the Usa River basin, northeastern European Russia (in preparation).

Zvereva, E., Kozlov, M., Neuvonen, S., 1995. Population density and performance of Melasoma lapponica (Coleoptera: Chrysomelidae) in surroundings of smelter complex. Environmental Entomology 24, $707-715$.

Zvereva, E., Kozlov, M., 2000. Effects of air pollution on natural enemies of the leaf beetle Melasoma lapponica. Journal of Applied Ecology 37, 298-308. 